The University of Maine

DigitalCommons@UMaine

Publications

Senator George J. Mitchell Center for Sustainability

Solutions

$3-2012$

\title{
Science Communication and Vernal Pool Conservation: A Study of local decision maker attitudes in a knowledge-action system
}

Bridie McGreavy

University of Maine, bridie.mcgreavy@maine.edu

Thomas Webler

Aram J K Calhoun

University of Maine, Calhoun@maine.edu

Follow this and additional works at: https://digitalcommons.library.umaine.edu/

mitchellcenter_pubs

Part of the Environmental Education Commons, Environmental Studies Commons, and the Life $\underline{\text { Sciences Commons }}$

\section{Repository Citation}

McGreavy, Bridie; Webler, Thomas; and Calhoun, Aram J K, "Science Communication and Vernal Pool Conservation: A Study of local decision maker attitudes in a knowledge-action system" (2012). Publications. 52.

https://digitalcommons.library.umaine.edu/mitchellcenter_pubs/52 


\section{Science communication and vernal pool conservation: A study of local decision maker attitudes in a knowledge-action system}

Bridie McGreavy $^{\mathrm{a}, *}$, Thomas Webler ${ }^{\mathrm{b}, 1}$, Aram J.K. Calhoun ${ }^{\mathrm{c}, 2}$

Antioch University New England, 40 Avon Street, Keene, NH 03431, United States

${ }^{b}$ Social and Environmental Research Institute, 278 Main Street, Suite 404, Greenfield, MA 01301, United States

'Department of Wildlife Ecology, University of Maine, Orono, ME 04469, United States

* Corresponding author. Present address: University of Maine, Margaret Chase Smith Policy Center, 5784 York

Complex, Bldg. \#4, Orono, ME 04473, United States. Tel.: p1 2075952240 (mobile).

E-mail addresses: bridie.mcgreavy@maine.edu (B. McGreavy), twebler@seri-us. org (T. Webler), calhoun@maine.edu (A.J.K. Calhoun).

Tel.: +14133879717 .

Tel.: +1 2075813010 . 


\section{ABSTRACT}

In this study, we describe local decision maker attitudes towards vernal pools to inform science communication and enhance vernal pool conservation efforts. We conducted interviews with town planning board and conservation commission members $(n=9)$ from two towns in the State of Maine in the northeastern United States. We then mailed a questionnaire to a stratified random sample of planning board members in August and September 2007 with a response rate of $48.4 \%$ ( $n$ $=320)$. The majority of survey respondents favored the protection and conservation of vernal pools in their towns. Decision makers were familiar with the term "vernal pool" and demonstrated positive attitudes to vernal pools in general. General appreciation and willingness to conserve vernal pools predicted support for the 2006 revisions to the Natural Resource Protection Act regulating Significant Vernal Pools. However, $48 \%$ of respondents were unaware of this law and neither prior knowledge of the law nor workshop attendance predicted support for the vernal pool law. Further, concerns about private property rights and development restrictions predicted disagreement with the vernal pool law. We conclude that science communication must rely on specific frames of reference, be sensitive to cultural values, and occur in an iterative system to link knowledge and action in support of vernal pool conservation.

Keywords: Sustainability science, Science communication, Knowledge-action, Vernal pools, Local decision makers, Attitudes, Interviews, Survey, Multivariate analysis 


\section{Introduction}

In an era of rapid global change in climate, terrestrial ecosystems and water resources, the role of science to identify environmental problems and pose solutions has never been more relevant. Yet the application of science to solve problems requires integration with decision making processes that occur across scales (Kates et al., 2001). A call for a new social contract between science and society to foster sustainable development arose at the end of the 20th century (Gallopin et al., 2001; Lubchenco, 1998). Sustainability science is an emerging field within this new social contract in which researchers investigate the character of nature-society relationships, or social ecological systems (SES), to build human capital, promote social learning, and strengthen the management of natural resources (Clark and Dickson, 2003; Folke et al., 2005; Kates et al., 2001).

Knowledge of the interactions between social and ecological systems is critical to identify solutions for sustainable development (Cash et al., 2003; Kates et al., 2001). However, knowledge must be accompanied by actions to implement solutions to integrated problems (Cash et al., 2003; van Kerkhoff and Lebel, 2006). The salience of the research problem, the credibility of the researchers and the information they produce, and the perceived legitimacy of science process are central to success in linking knowledge and action (Cash et al., 2003). Hart and Calhoun (2010) describe a vernal pool research program that actively works to link knowledge and action to improve decision making for sustainable development and vernal pool conservation. The iterative process of engagement between vernal pool scientists and stakeholders which they describe led to the most comprehensive vernal pool legislation in the United States (Hart and Calhoun, 2010).

Vernal pools are temporary to semi-permanent wetlands found in forests throughout the 
northeastern United States that provide critical breeding habitat for amphibians adapted to life in temporary waters. They also provide a range of ecosystem services within the forested landscape, including foraging and resting habitat for a variety of mammals, birds, and reptiles (Mitchell et al., 2007). They provide biological connectivity between wetland complexes and terrestrial systems (Baldwin et al., 2006; Gibbs, 2000) and facilitate nutrient cycling (Gibbons et al., 2006; King, 1985). But, vernal pools are increasingly threatened by development pressures and land-use activities that degrade wetlands and fragment forested habitats (Baldwin and deMaynadier, 2009; Calhoun et al., 2005; Windmiller and Calhoun, 2008).

The 2006 revisions to Maine's Natural Resource Protection Act for Significant Vernal Pools regulate a subset of vernal pools that support breeding populations of spotted salamanders Ambystoma maculatum, blue spotted salamanders Ambystoma laterale, wood frogs Rana sylvatica, and fairy shrimp Eubranchipus spp. (Department of Environmental Protection, 2006). However, the law only regulates a minimal radial core or zoned area of 250 feet $(76.2 \mathrm{~m})$ around the pool and permits development of up to $25 \%$ of the core zone. Although preservation of the core terrestrial habitat may maintain some vernal pool ecosystem processes, this approach does not conserve the landscape scale processes that support amphibian population persistence (Baldwin and deMaynadier, 2009; Calhoun et al., 2005; Gamble et al., 2006, 2007; Gibbs and Reed, 2008). Given the dispersal needs of vernal pool amphibians, landscape scale conservation planning at the beginning stages of urbanization is critical to preserve functional amphibian habitat (Baldwin et al., 2006; Baldwin and deMaynadier, 2009).

Landscape scale planning for vernal pool conservation will require engaged communication between scientists, decision makers, and other stakeholders (Hart and Calhoun, 2010). Through 
dialogic participation and engagement, scientists and stakeholders may find common ground to form a community of researchers and practitioners (van Wyk et al., 2008). In this community, scientists may respond to the needs of the public to draft management plans, design empirical tests, and interpret data and patterns. As a result, stakeholders may gain a deeper appreciation for the process of science and inherent uncertainty in scientific problems and solutions (Norton, 1998).

Research on environmental attitudes and worldviews provides insights into the frames of reference around which people construct meaning and may support efforts to identify common ground between scientists and stakeholders (Cash et al., 2003; Nisbet and Scheufele, 2009; St John et al., 2010; van Wyk et al., 2008). Several studies have used interviews and surveys to identify attitudes towards vernal pool and wetland conservation to inform education and land use planning (Johnson and Pflugh, 2008; Preisser et al., 2000; Rispoli and Hambler, 1999; Sah and Heinen, 2001). The New Environmental Paradigm (NEP) is a measure of environmental worldviews that may intersect with attitudes to influence positive and negative views towards environmental issues (Dunlap and Liere, 1978; Dunlap et al., 2000). The NEP scale seeks to measure environmental worldviews with twelve questions that orient on two dimensions, including the New Environmental and the Dominant Social Paradigms, to reflect specific attitudes towards the environment. Both the original and revised versions of the NEP have been used widely in studies of environmental attitudes throughout the world (Bostrom et al., 2006; Corral-Verdugo and Armendariz, 2000; Flaten et al., 2010; Hunter and Rinner, 2004; Sah and Heinen, 2001).

\subsection{Research objectives}


Our study connects attitude research with science communication theory to inform an iterative process of linking knowledge and action to improve landscape scale planning for vernal pool conservation. Because we draw on science communication theory to make recommendations based on empirical evidence, our study of attitudes to a natural resource management issue differs from others in this field. Extensive research on attitudes towards natural resources describes actual or projected behavior, in many cases drawing on the theories of reasoned action and planned behavior (Ajzen and Fishbein, 1980; St John et al., 2010). Researchers have examined attitudes and projected behavior towards protected areas (Dimitrakopoulos et al., 2010), ecological restoration (Bright et al., 2002), green spaces (Balram and Dragicevic, 2005), timber harvesting (Schaaf et al., 2006), wildlife management (McCleery, 2009), recycling (Grodzinska-Jurczak et al., 2006), and water quality Best Management Practices (Greiner et al., 2009).

Though we seek to describe intended behavior, more centrally we aim to identify decision maker attitudes to inform communication processes to improve the implementation of vernal pool regulations at the municipal level. While our research focused on vernal pool regulation in Maine, our empirical method for describing attitudes to enhance science communication are relevant for a range of natural resource management issues (Nisbet and Scheufele, 2009).

Our research objectives were to:

1) Use interviews and a state-wide survey to describe local decision maker attitudes toward vernal pools and associated regulations

2) Identify components and relationships between attitudes and environmental worldviews to describe frames of reference for vernal pools

3) Use frames of reference to provide communication recommendations to support vernal 
pool conservation at the municipal scale.

\section{Methods}

We used themes from interviews and participant observations to design a subsequent postal survey. This methodology allowed the analysis of attitudes to take place on two levels: in-depth qualitative data from interviews and expanded quantitative data from a state-wide questionnaire (Buijs, 2009; Creswell, 2003; Kempton et al., 1996; Larson and Lach, 2008). In this study, we defined attitudes as a latent construct based on cognitive, affective, and behavioral components (Bright et al., 2002) and local decision makers as town planning board, conservation commission, code enforcement officers and town council members.

\subsection{Sampling and interview methodology}

We investigated local decision maker attitudes to vernal pool conservation with semi-structured interviews and participant observations in Bar Harbor and Wayne, Maine, a state in the northeastern United States. We selected the towns of Bar Harbor and Wayne due to existing municipal efforts to protect vernal pools. We conducted interviews with willing local decision makers using a purposeful sampling scheme that employed snowball and criterion selection techniques (Creswell, 1998; Patton, 2002). We interviewed five conservation commission members in Wayne and two conservation commission members, one planning board and one town council member in Bar Harbor from April to May, 2007. Interviews lasted approximately $1 \mathrm{~h}$ and were digitally recorded for transcription. 
The interview protocol was semi-structured and in the first question we asked, "When I say the term 'vernal pool' what do you think of?" Subsequent questions focused on prior experience of vernal pools, perceptions and knowledge of vernal pool ecology, and state and municipal regulatory efforts to conserve vernal pools. In addition to interviews, we attended three public workshops to collect informal participant observations. We used content analysis to identify themes in the interviews and participant observations and these themes informed the development of questions and statements for the postal survey (Patton, 2002).

\subsection{Questionnaire methodology}

Our questionnaire consisted of 50 closed-ended questions, the majority of which used a six-point Likert scale to discourage ambiguous responses (Dillman, 2007; Likert, 1932). The questionnaire had three sections. Statements 1-17 measured general attitudes towards vernal pools. Statements $18-38$ focused on responses to the 2006 revisions to the Natural Resource Protection Act regulating Significant Vernal Pools. After respondents read a summary of the law, they responded to statements with a focus on private property rights, development restrictions, rural preservation, and mapping efforts. Statement 38 asked participants to rate the importance of vernal pool conservation in town politics. The final section, Statements $39-50$, used a version of the New Environmental Paradigm (NEP) to measure environmental world-views (Dunlap and Liere, 1978). We piloted the questionnaire with five current or former planning board members and made slight revisions to clarify questions based on data analysis and direct feedback from participants.

We mailed the questionnaire to a random sample $(n=700)$ of 2318 planning board members listed with the Maine Municipal Association (MMA), using a stratified sample design that attempted 
to include at least one respondent in each town in the State of Maine $(N=463)$. The questionnaire methodology followed a modified version of the Tailored Design Method (TDM) (Dillman, 2007). We sent a pre-letter on August 20th, 2007, followed by the survey four days later and a reminder post card two weeks after that. Three weeks after the post card, we drew a random sample $(\mathrm{n}=$ 250) of the 428 non-respondents and mailed them a second survey packet. To reduce costs, we modified the TDM by not using certified mail and by sending follow-up survey to a random sample of 250 non-respondents instead of all non-respondents.

\subsection{Data analysis}

We analyzed frequency data for all responses and created histograms to identify response trends and to look for indications of non-response bias, paying specific attention to the distribution of responses across the range of Likert scale categories (Hair et al., 2006; Hunter and Rinner, 2004). To summarize environmental worldviews, we created index scores for the New Environmental Paradigm by summing the Likert scale response for each statement, reversing scores on statements with negative orientations to the match response trends. When questions within the index were skipped by the respondent, we deleted the response from the index $(n=35)$ (Hair et al., 2006). For this study, the definition of ecocentrism and anthropocentrism followed Thompson and Barton's (1994) description of motivations for environmental concern, where ecocentrism emphasizes the inherent value in nature and anthropocentrism emphasizes human benefits from nature.

We employed an exploratory principal PCA with an orthogonal rotation to reduce and extract constructs from the questionnaire $(n=33)$ and the NEP scale $(n=12)$ (Flaten et al., 2010; Hair et al., 2006; Johnson and Pflugh, 2008; Nixon and Saphores, 2007). We used the Kaiser criterion to select 
principal components with Eigenvalues 21.0 because we had an $\mathrm{N}>250$ (Stevens, 2002), a mean communality $<0.6$, and the number of variables was between 20 and 50 (Hair et al., 2006). To define the components, we used a five-step process of interpretation (Hair et al., 2006): (1) After subjecting statements to a varimax rotation, we assigned factor pattern values 20.4 to a component. (2) We assessed communality values less than 0.4 for possible deletion (Flaten et al., 2010). (3) We looked for shared conceptual meaning and differentiation in the constructs and high loadings on a single factor. (4) We deleted variables $(n=4)$ that did not meet the interpretation criteria and recalculated the factors based on the reduced set of variables. Bartlett's test for sphericity and the Kaiser-Meyer-Olkin (KMO) allowed us to examine the level of intercorrelation between variables and our sampling adequacy (Nixon and Saphores, 2007). (5) We measured the internal consistency of final components with a reliability coefficient (Cronbach's alpha) (Hair et al., 2006). We used a pairwise deletion approach for dealing with missing data (Vaske, 2008).

We performed multiple linear regressions to determine the degree of association between prior knowledge and workshop attendance; attitude constructs; and environmental worldviews with response to Statement 20. I think this law is necessary and I support it (Connelly et al., 2003; Flaten et al., 2010; Hair et al., 2006; Johnson and Pflugh, 2008; Sullivan and Napier, 2005). The independent variables consisted of the dummy coded responses (Yes $=1$ ) to Question 2. (Have you ever attended a workshop or educational event focused on vernal pools?) and Question 18 (Prior to receiving this survey, did you know that this law was being enacted?); the mean responses to the variables associated with principal component attitude constructs; and the mean responses to the principal components from the NEP. The dependent variable was the Likert response to Statement 20. We conducted listwise deletions for missing responses and assessed collinearity with a toler- 
ance factor (Vaske, 2008). For the analysis we used SPSS Statistics Version 19 and statistical significance was determined with $95 \%$ confidence levels $(a<0.05)$.

3. Results

3.1 Interview themes

The content analysis of interviews with local decision makers revealed several themes, and here we provide a summary to demonstrate the descriptive richness and application of the themes to the subsequent postal questionnaire. Participants discussed a range of values associated with vernal pools, including ecological values, the importance of vernal pools for rural preservation efforts, potential economic value for real estate and tourism, and the importance of vernal pools in education and for future generations. The theme that vernal pools are valuable for future generations was captured in this quotation:

And I would not say that people love it [vernal pools]; they would say it is here and we do want to show our kids the frogs and salamanders. There is a richness that we can't bring back once it is gone.

Participants expressed the perception that the science behind decision making is not always transparent. One decision maker said:

...I would have to know how they came up with the 250 feet. How did they come up with 40 egg sacs, as opposed to 50 or 35 ? Where, I understand that there is probably somebody that made that decision but I hope it is not just a group of people sitting in a room saying, "Oh, 40 sounds good." Because I think sometimes that is what 
happens.

Several concerns related to vernal pool regulations emerged from the interviews, most notably about impacts to private property rights. Private property rights concerns were further distinguished into specific orientations, including fears about eminent domain, property boundary issues, limits to the development potential of the land and the implications for investment and retirement savings. Speaking about private property rights, a decision maker asked:

Have we gone too far? I don't know that. I think there is a balance between protecting landowner rights and protecting vernal pools. Is it attainable? There is no question in my mind that it is attainable. But the question is the legislation has to be crafted to do that.

Participants also expressed place-based concerns related to the dominant land use in the town. For example, in the largely agricultural landscape of Wayne, people expressed concern that their "farm pond down back" would be regulated under the new legislation.

\subsection{Survey response distribution}

The response rate for this questionnaire was $48.4 \%$, based on a return rate of 328 out of 677 questionnaires. A total of 700 questionnaires were initially mailed, with 23 rejected due to incorrect addresses. Of the 328 returned questionnaires, 320 yielded useable questionnaire data. Below we highlight descriptive responses that are particularly salient to the communication recommendations in the following discussion section. 


\subsubsection{Vernal pool knowledge}

Most planning board members were familiar with the term 'vernal pool', as $88.5 \%$ of respondents indicated that they had heard the term prior to receiving the questionnaire (see Table 1). Eighty-four percent expressed confidence that they knew what a vernal pool was (Statement 3). Seventy-nine percent of respondents indicated a basic knowledge of vernal pool ecology, indicating agreement with the statement, "Without vernal pools, some animal populations would decline significantly" (Statement 7). When asked if they had ever visited a vernal pool, $77.6 \%$ indicated that they had (Statement 14).

More than half $(57.7 \%)$ did not recognize the need for larger terrestrial habitats and connectivity between pools (Statement 22 ), yet a majority (72.4\%) did indicate that they would like to learn more about vernal pools (Statement 4). Ninety percent agreed that there is value in teaching children about vernal pools (Statement 15).

When asked specifically about the vernal pool law, 48\% percent indicated they did not know about the new regulations prior to receiving the questionnaire (Question 18). Fifty-six percent of respondents agreed with Statement 19, indicating that they thought the new law was a good idea. Eighty percent of respondents indicated that they wanted to know more about the science behind the vernal pool law (Statement 28 ) and $76.6 \%$ indicated they generally agree with the conservation recommendations that scientists make (Statement 8).

\subsection{Attitude constructs}

The initial unrestricted principal components analysis (PCA) revealed six questionnaire 
components (eigenvalues 21.0). An interpretation of the rotated factor pattern reduced to four components, which we labeled: 1) Concerns about private property rights, enforcement, and restrictions, 2) Appreciation and willingness to conserve, 3) Knowledge and experience and 4) Interest in knowing more (Table 2). Two components were removed because they did not meet the interpretability criteria. Our sample size was adequate (KMO = 0.954), our variables were related and suitable for structure detection based on the Bartlett's test of sphericity $\left(\mathrm{x}^{2}=4987.2, p<\right.$ 0.001), and the final constructs demonstrated inter-item reliability $(\alpha>0.6)$.

\subsection{Environmental worldviews}

Overall, decision makers demonstrated ecocentric worldviews, as the mean NEP response was $2.05(S D=0.9)$, the mean index score was $30.7(S D=11.2)$ and $71.9 \%$ of respondents scored in the two lowest index score categories (Fig. 1). The scale loaded on two factors, including statements associated with the New Environmental Paradigm (eigenvalue $=5.08$ ) and Dominant Social Paradigm (eigenvalue $\mathbf{1 . 4 3}$ ) respectively (Table 3 ).

\subsection{Predictive relationships}

The overall multiple regression model, with prior knowledge; workshop attendance; concerns; appreciation; knowledge and experience; interest in knowing more; and environmental world-views as predictors of response to the law, was significant $(F(8141)=57.39, p<0.001)$ (Table 4). Controlling for all other variables, a one unit increase in concerns resulted in 0.55 decrease in agreement with the vernal pool law $(\mathrm{t}(141)=-6.082, p<0.001)$. A one unit increase in appreciation resulted in a 0.65 increase in agreement with the law $(t(141)=5.612, p<0.001)$. No other 
relationships were significant $(a=0.05)$ and we did not encounter any collinearity issues using the tolerance factor (all values $>0.2$ ).

\section{Discussion}

As Nisbet and Scheufele (2009) argue, “...any science communication efforts need to be based on a systematic empirical understanding of an intended audience's existing values, knowledge, and attitudes, their interpersonal and social contexts, and their preferred media sources and communication channels" (p.1767). Our description of attitude constructs and environmental worldviews provides an empirical framework for making decisions about the kind of information decision makers want to know and the frames of reference they may use for evaluating that information (Nisbet and Scheufele, 2009; Nisbet, 2009; Norton, 1998; Weber and Word, 2001).

We found the majority of respondents to the questionnaire favored protecting vernal pools, generally supported the law, and demonstrated ecocentric worldviews. We also found that general appreciation and willingness to conserve vernal pools positively predicted support for the vernal pool law. However, concerns about property rights, development restrictions, and loss of local control predicted disagreement with the vernal pool law. These concerns, in addition to general appreciation and willingness, were clearly constructs in vernal pool attitudes that helped explain response to the vernal pool law.

The result that $48 \%(n=153)$ of respondents were unaware of the vernal pool law before receiving the questionnaire and that prior knowledge and workshop attendance did not significantly predict response to the law raises interesting implications for science communication 
efforts. The transfer and translate model of science communication assumes that knowledge about natural resources will result in acceptance of the science that supports NEP Index scores conservation laws (Allum et al., 2008; Bauer et al., 2007; Nisbet and Scheufele, 2009). In this approach, enhancing scientific literacy is seen as central to improving natural resource conservation and some studies have revealed a small but positive relationship that supports this assumption (Allum et al., 2008).

While our study does not empirically support the conclusion that prior knowledge leads to more positive attitudes, decision makers may still need basic scientific and regulatory information to make decisions (Doremus, 2008). Research on the ways in which decision makers access information demonstrates the importance of using local news outlets, radio, and television (Halseth and Booth, 2003). A more recent analysis by Illes et al. (2010) provides several recommendations for innovative media technologies that may be used in science communication efforts, including podcasts, blogs, online discussion forums, science salons, and science cafes. Thus, a key question for future analysis will be to examine the ways in which decision makers prefer to receive information to improve the transmission of information from science and policy maker to local management contexts.

In addition to basic information needs, communication strategies to promote vernal pool conservation must engage issues of personal relevance (Tarrant and Overdevest, 1997). Messages about private property rights, impacts to development, and enforcement challenges should be central to communication efforts aimed at linking knowledge and action to enhance vernal pool conservation and the adoption of Best Development Practices (BDPs). Planning board members also need and want to know more about the scientific foundation that informed the law (Hart and 
Calhoun, 2010) and the landscape ecology of vernal pool species that BDPs help preserve (Calhoun et al., 2005). Further, communication around vernal pools should also feature the multiple values associated with vernal pools, including ecologic, intrinsic, esthetic and rural preservation (Norton, 1998). Indeed, the most salient message about of vernal pools may be their educational value, as $90 \%$ of respondents agreed that children should learn about vernal pools.

Presentations and publications associated with the Maine Vernal Pools Project are already including information about the science of conservation and landscape ecology in presentations to promote vernal pool conservation in Maine towns (Calhoun et al., 2010). Because this research is set within an iterative process of linking knowledge and action, additional studies are underway through the Sustainability Solutions Initiative to better understand the intersection of vernal pool conservation and other natural resource issues with economic and social concerns such as private property rights and economic development restrictions (Hart and Calhoun, 2010).

In sum, the implications of our study for science communication may be conceptualized along three orientations. First, decision makers must have a basic awareness of changes to land use laws and this awareness may be cultivated through a variety of print and online media. Second, communication about those laws and associated BDPs to improve landscape scale planning around vernal pool conservation should be sensitive to information needs and cultural values. Participants have specific attitudes that may guide the ways in which they perceive and process science information. Concerns about private property rights and economic development restrictions along with general appreciation and willingness to conserve vernal pools are important attitude constructs in how people evaluate vernal pool conservation. And third, knowledge of these attitudes and how they predict response to vernal pool laws contributes to a knowledge-action 
system in which the critical boundary between scientists and stakeholders is better understood.

This awareness supports inclusive and participatory communication that is respectful and cognizant of multiple frames of reference and cultural differences to enhance vernal pool conservation efforts at the municipal scale.

\section{Conclusions}

Our description of decision maker attitudes provides a snapshot in time; the conclusions we derived from the interviews, participant observations, and questionnaire analyses would likely be different if we were to conduct these studies again. For example, the vernal pool attitudes study occurred before the economic downturn of 2008. It is likely that expressed concerns about the economic impacts of vernal pool regulations would be stronger now and feelings of general appreciation and willingness to conserve weaker. The temporal fluidity of social systems underlines the critical importance of iterative knowledge-action systems that take more than a single snapshot in time (van Kerkhoff and Lebel, 2006). This study sought to inform this iterative process in ways that will potentially help support long-term relationships between communities of scientists and decision makers through communication processes that are inclusive, respectful, and relevant. 
FIGURES

Table 1

Frequency of responses to categorical variables.

\begin{tabular}{|c|c|c|c|c|c|}
\hline Response variable & $N$ & Missing & Skipped $^{\mathrm{a}}$ & Yes $(\%)$ & No $(\%)$ \\
\hline 1) Have you heard the term "vernal pool" before receiving this survey? & 305 & 15 & $\sim$ & 88.5 & 11.5 \\
\hline $\begin{array}{l}\text { 2) Have you ever attended a workshop } \\
\text { or educational event focused on vernal pools? }\end{array}$ & 252 & 33 & 35 & 75.0 & 25.0 \\
\hline 19) Do you think this law is a good idea? & 303 & 17 & $\sim$ & 56.4 & 43.6 \\
\hline
\end{tabular}

${ }^{a}$ This item reflects skipped responses due to questionnaire instruction which directed respondents to skip all remaining items in the first section of the survey if they responded No to Question 1. 
Table 2

Latent attitude constructs in the questionnaire: Varimax factor rotation.

\begin{tabular}{|c|c|c|c|c|c|}
\hline \multirow[t]{2}{*}{ Response variables $(n=29)$} & \multicolumn{4}{|c|}{ Rotated factor loadings $^{\mathrm{a}}$} & \multirow[t]{2}{*}{ Communality } \\
\hline & 1 & 2 & 3 & 4 & \\
\hline \multicolumn{6}{|l|}{ 1. Concerns $(\alpha=0.95)^{\mathrm{b}}$} \\
\hline 24) The vernal pool law will make it too hard to subdivide land for family inheritance. & 0.82 & -0.27 & -0.09 & -0.02 & 0.75 \\
\hline $\begin{array}{l}\text { 27) Requiring landowners to conserve vernal pools would unduly } \\
\text { limit residential and commercial development. }\end{array}$ & 0.82 & -0.33 & -0.03 & -0.06 & 0.78 \\
\hline 23) The state has too much control over what people can do on their property. & 0.81 & -0.27 & 0.01 & -0.12 & 0.75 \\
\hline 26) I am concerned that if my neighbor has a vernal pool, my property may be regulated too. & 0.78 & -0.23 & -0.02 & 0.09 & 0.67 \\
\hline 37) Private property rights are more important than vernal pool conservation. & 0.78 & -0.41 & -0.10 & -0.12 & 0.79 \\
\hline $\begin{array}{l}\text { 30) The State of Maine already has a lot of land in conservation } \\
\text { and does not need to regulate more land with this law. }\end{array}$ & 0.75 & -0.47 & -0.01 & -0.08 & 0.79 \\
\hline 34) Requiring landowners to conserve vernal pools goes against private property rights. & 0.75 & -0.40 & -0.02 & -0.07 & 0.73 \\
\hline 9) The State of Maine has too many environmental regulations. & 0.73 & -0.30 & 0.09 & -0.10 & 0.65 \\
\hline 33) Vernal pool regulations will negatively affect my town. & 0.72 & -0.47 & 0.01 & -0.02 & 0.74 \\
\hline 29) Vernal pool conservation will limit affordable housing options. & 0.72 & -0.31 & 0.03 & 0.12 & 0.63 \\
\hline 21) This law will be too difficult to enforce. & 0.51 & -0.12 & -0.05 & -0.14 & 0.30 \\
\hline \multicolumn{6}{|l|}{ 2. Appreciation and willingness ( $\alpha=0.93$ ) } \\
\hline 6) My town should try to conserve vernal pools. & -0.45 & 0.77 & 0.05 & 0.14 & 0.81 \\
\hline 5) If I had a vernal pool on my property, I would try to protect it. & -0.44 & 0.74 & 0.12 & 0.10 & 0.77 \\
\hline $\begin{array}{l}\text { 13) I think that most people in my town would want } \\
\text { to protect vernal pools if they know about them. }\end{array}$ & -0.26 & 0.72 & 0.04 & 0.14 & 0.60 \\
\hline 7) Without vernal pools, some animal populations would decline significantly. & -0.32 & 0.70 & 0.12 & 0.11 & 0.62 \\
\hline $\begin{array}{l}\text { 38) On a scale of } 1-10 \text {, where } 1 \text { is most important and } 10 \text { is least important, } \\
\text { circle where you would place vernal pool conservation in your town politics. }\end{array}$ & -0.29 & 0.66 & 0.04 & -0.08 & 0.53 \\
\hline 12) There is a mystique to vernal pools that makes them appealing. & -0.22 & 0.64 & -0.05 & 0.12 & 0.47 \\
\hline 36) If protecting vernal pools helped maintain the rural character of my town, I would support it. & -0.51 & 0.61 & -0.01 & 0.07 & 0.64 \\
\hline 15) There is value in teaching children about vernal pools. & -0.33 & 0.60 & 0.16 & 0.33 & 0.60 \\
\hline 10) For the most part, protecting vernal pools will enhance property values. & -0.47 & 0.59 & 0.01 & 0.01 & 0.57 \\
\hline 25) I think all vernal pools should be located and mapped. & -0.41 & 0.53 & 0.04 & 0.20 & 0.49 \\
\hline 31) If I had a vernal pool on my property, I would tell the appropriate regulatory person. & -0.56 & 0.51 & -0.02 & 0.07 & 0.58 \\
\hline 8) I usually agree with the conservation recommendations scientists make. & -0.50 & 0.48 & 0.03 & 0.13 & 0.50 \\
\hline \multicolumn{6}{|l|}{ 3. Knowledge and experience $(\alpha=0.64)$} \\
\hline $\begin{array}{l}\text { 35) I understand the difference between a vernal pool and the State's } \\
\text { definition of a Significant Vernal Pool. }\end{array}$ & 0.09 & -0.05 & 0.74 & -0.13 & 0.57 \\
\hline 17) I am not familiar with the State's Significant Wildlife Habitat Rules. & 0.23 & 0.22 & -0.71 & 0.02 & 0.60 \\
\hline 14) I have visited a vernal pool. & 0.00 & 0.20 & 0.67 & 0.24 & 0.55 \\
\hline 3) I feel confident that I know what a vernal pool is. & 0.05 & 0.32 & 0.66 & -0.14 & 0.56 \\
\hline \multicolumn{6}{|l|}{ 4. Interest in knowing more $(\alpha=0.60)$} \\
\hline 28) I would like to know more about the science behind this law. & 0.11 & 0.10 & -0.05 & 0.86 & 0.76 \\
\hline \multirow[t]{2}{*}{ 4) I would like to learn more about vernal pools. } & -0.28 & 0.25 & -0.06 & 0.71 & 0.64 \\
\hline & & & & & Total \\
\hline Sum of squares (eigenvalues) & 13.35 & 2.06 & 1.87 & 1.16 & 18.45 \\
\hline Percent of variance (\%) & 46.03 & 7.12 & 6.46 & 4.01 & 63.62 \\
\hline
\end{tabular}

${ }^{a}$ Factors 1-4 include Concerns about private property rights and economic development restrictions, General appreciation and willingness to conserve, Knowledge and experience, and Interest in knowing more. Factor loadings $\geq 0.4$ shown in bold. Variables that did not meet the 5 part measure of interpretability were removed from the reported PCA model.

b Cronbach's alpha reliability coefficients. 


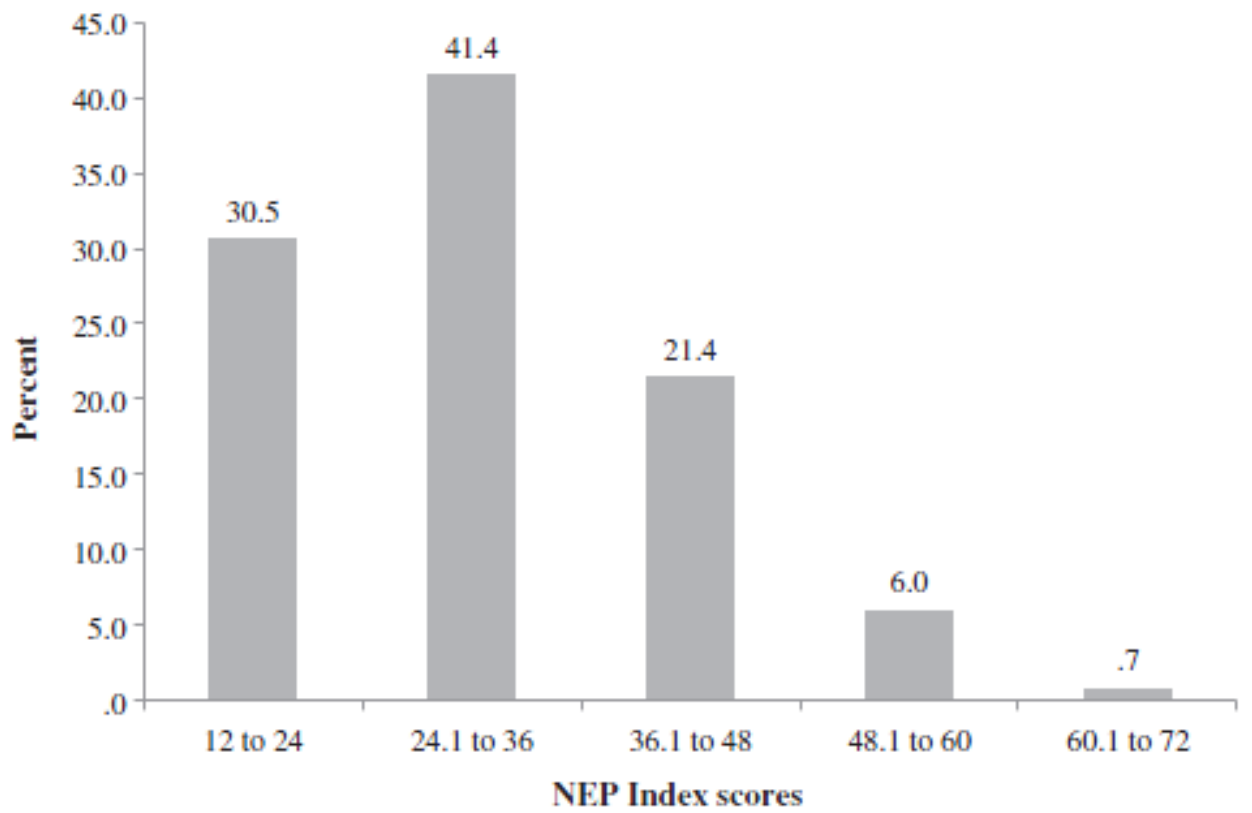

Fig. 1. Percentage of responses in each of the New Environmental Paradigm (NEP) Index score categories. Index scores for the NEP were created by summing the Likert scale response for each statement. Low scores indicate ecocentric responses. High scores indicate anthropocentric responses (Thompson and Barton, 1994). 
Table 3

Environmental worldviews: Varimax factor rotation of the New Environmental Paradigm.

\begin{tabular}{|c|c|c|c|}
\hline \multirow[t]{2}{*}{ Response variables $(n=12)$} & \multicolumn{2}{|c|}{ Rotated factor loadings $^{\mathrm{a}}$} & \multirow[t]{2}{*}{ Communality } \\
\hline & 1 & 2 & \\
\hline \multicolumn{4}{|l|}{ 1. New environmental paradigm $(\alpha 0.86)^{\mathrm{b}}$} \\
\hline 39-9) The earth is like a spaceship with only limited room and resources. & 0.79 & -0.18 & 0.65 \\
\hline 39-12) Mankind is severely abusing the environment. & 0.75 & -0.26 & 0.63 \\
\hline 39-11) There are limits to growth beyond which our industrialized society cannot expand. & 0.75 & -0.01 & 0.56 \\
\hline 39-8) Humans must live in harmony with nature in order to survive. & 0.68 & -0.18 & 0.50 \\
\hline $39-2)$ The balance of nature is very delicate and easily upset. & 0.64 & -0.35 & 0.54 \\
\hline 39-1) We are approaching the limit of the number of people the Earth can support. & 0.62 & -0.34 & 0.50 \\
\hline 39-5) When humans interfere with nature it often produced disastrous consequences. & 0.61 & -0.18 & 0.40 \\
\hline $\begin{array}{l}\text { 39-7) To maintain a healthy economy, we will have to develop a steady } \\
\text { state economy where industrial growth is controlled }\end{array}$ & 0.60 & -0.17 & 0.39 \\
\hline \multicolumn{4}{|l|}{ 2. Dominant social paradigm $(\alpha=0.77)$} \\
\hline 39-4) Humankind was created to rule over the rest of nature. & -0.16 & 0.85 & 0.75 \\
\hline 39-6) Plants and animals exist primarily to be used by humans. & -0.14 & 0.83 & 0.71 \\
\hline 39-3) Humans have the right to modify the natural environment. & -0.18 & 0.70 & 0.52 \\
\hline \multirow[t]{2}{*}{$\begin{array}{l}\text { 39-10) Humans need not adapt to the natural environment because } \\
\text { they can remake it to suit their needs. }\end{array}$} & -0.34 & 0.53 & 0.39 \\
\hline & & & Total \\
\hline Sum of squares (eigenvalues) & 5.08 & 1.47 & 6.55 \\
\hline Percent of variance $(\%)$ & 42.32 & 12.28 & 54.60 \\
\hline
\end{tabular}

${ }^{a}$ Factor 1 includes New Environmental Paradigm statements. Factor 2 includes Dominant Social Paradigm Statements. Factor loadings $\geq 0.4$ shown in bold. All variables were included in the final model.

b Cronbach's alpha reliability coefficients. 
Table 4

Multiple linear regressions measuring degree of association between prior knowledge, attitude constructs and environmental worldviews with response to the vernal pool law.

\begin{tabular}{lrrr}
\hline & \multicolumn{1}{l}{$b$} & SE $b$ & \multicolumn{1}{l}{$\beta$} \\
\hline Constant $^{l}$ & 3.18 & 0.83 & \\
Ecocentric worldview $^{\mathrm{a}}$ & 0.03 & 0.09 & 0.02 \\
Anthropocentric worldview $^{\mathrm{a}}$ & -0.04 & 0.08 & -0.03 \\
Private property and economic concerns $^{\mathrm{b}}$ & -0.55 & 0.09 & $-0.44^{\cdots \cdots}$ \\
Appreciation and willingness to conserve $^{\mathrm{b}}$ & 0.65 & 0.12 & $0.44^{\cdots \cdots}$ \\
Knowledge and experience $^{\mathrm{b}}$ & -0.02 & 0.09 & -0.01 \\
Interest in knowing more $^{\mathrm{b}}$ & 0.05 & 0.06 & 0.04 \\
Workshop attendance $^{c}$ & -0.06 & 0.17 & -0.02 \\
Prior knowledge $^{\mathrm{c}}$ & -0.05 & 0.15 & -0.01 \\
\hline
\end{tabular}

$\cdots p \leq 0.0001$. Standardised regression coefficients. $R^{2}=0.77$ for the model.

${ }^{a}$ Mean Likert scores for variables associated with factors in the NEP scale.

b Mean Likert scores for variables associated with factors extracted from the survey.

c Measured as a dummy variable where " 1 "denotes Yes and " 0 " denotes No. 


\section{REFERENCES}

Ajzen, I., Fishbein, M., 1980. Understanding Attitudes and Predicting Social Behavior. Prentice-Hall, Inc., Englewood Cliffs, New Jersey.

Allum, N., Sturgis, P., Tabourazi, D., Brunton-Smith, I., 2008. Science knowledge and attitudes across cultures: a meta-analysis. Public Understanding of Science 17 (1), 35e54.

Baldwin, R.F., Calhoun, A.J.K., deMaynadier, P.G., 2006. Conservation planning for amphibian species with complex habitat requirements: a case study using movements and habitat selection of the wood frog Rana Sylvatica. Journal of Herpetology 40 (4), 442e453.

Baldwin, R.F., deMaynadier, P.G., 2009. Assessing threats to pool-breeding amphibian habitat in an urbanizing landscape. Biological Conservation 142 (8), $1628 \mathrm{e} 1638$.

Balram, S., Dragicevic, S., 2005. Attitudes toward urban green spaces: integrating questionnaire survey and collaborative GIS techniques to improve attitude measurements. Landscape and Urban Planning 71 (2-4), 147e162.

Bauer, M.W., Allum, N., Miller, S., 2007. What can we learn from 25 years of PUS survey research? Liberating and expanding the agenda. Public Understanding of Science 16 (1), 79 e95.

Bostrom, A., Barke, R., Turaga, R.M.R., O'Connor, R.E., 2006. Environmental concerns and the new environmental paradigm in Bulgaria. Journal of Environmental Education 37 (3), $25 \mathrm{e} 40$.

Bright, A.D., Barro, S.C., Burtz, R.T., 2002. Public attitudes toward ecological restoration in the Chicago metropolitan region. Society and Natural Resources 15 (9), $763 \mathrm{e} 785$.

Buijs, A.E., 2009. Public support for river restoration. A mixed-method study into local residents' support for and framing of river management and ecological restoration in the Dutch floodplains. Journal of Environmental Management 90 (8), 2680e2689.

Calhoun, A.J.K., Morgan, D., Carey, R., 2010. Maine Vernal Pools Project. [PowerPoint Slides]. Retrieved from http://www.umaine.edu/vernalpools/PowerPoints.html.

Calhoun, A.J.K., Miller, N., Klemens, M., 2005. Conserving pool-breeding amphibians in human-dominated landscapes through local implementation of best development practices. Wetlands Ecology and Management 13 (3), $291 \mathrm{e} 304$.

Cash, D.W., Clark, W.C., Alcock, F., Dickson, N.M., Eckley, N., Guston, D.H., et al., 2003. Knowledge systems for sustainable development. Proceedings of the National Academy of Sciences of the United States of America 100 (14), 8086.

Clark, W.C., Dickson, N.M., 2003. Sustainability science: the emerging research program. Proceedings of the National Academy of Sciences of the United States of America 100 (14), 8059 e8061.

Connelly, N.A., Brown, T.L., Decker, D.J., 2003. Factors affecting response rates to natural resource-focused mail surveys: empirical evidence of declining rates over time. Society and Natural Resources 16 (6), 541.

Corral-Verdugo, V., Armendariz, L.I., 2000. The 'new environmental paradigm' in a Mexican community. Journal of Environmental Education 31 (3), 25.

Creswell, J.W., 1998. Qualitative Inquiry and Research Design: Choosing Among Five Traditions. Sage Publications, Inc., Thousand Oaks, California.

Creswell, J.W., 2003. Research Design: Qualitative, Quantitative and Mixed Methods Approaches. Sage Publications, Thousand Oaks, California.

Dillman, D.A., 2007. Mail and Internet Surveys: The Tailored Design Method. John Wiley and Sons, Inc., Hoboken, New Jersey. 
Dimitrakopoulos, P.G., Jones, N., losifides, T., Florokapi, I., Lasda, O., Paliouras, F., et al., 2010. Local attitudes on protected areas: evidence from three Natura 2000 wetland sites in Greece. Journal of Environmental Management 91 (9), 1847e1854.

Doremus, H., 2008. Data gaps in natural resource management: sniffing for leaks along the information pipeline. Indiana Law Journal 83 (2), 407e463.

Dunlap, R.E., Liere, K.D.V., 1978. The "New Environmental Paradigm": a proposed measuring instrument and preliminary results. Journal of Environmental Education 9, 10e19.

Dunlap, R.E., Liere, K.D.V., Mertig, A.G., Jones, R.E., 2000. Measuring endorsement of the new ecological paradigm: a revised NEP scale. Journal of Social Issues 56 (3), 425e442.

Flaten, O., Lien, G., Koesling, M., Løes, A.K., 2010. Norwegian farmers ceasing certified organic production: characteristics and reasons. Journal of Environmental Management 91 (12), 2717 e2726.

Folke, C., Hahn, T., Olsson, P., Norberg, J., 2005. Adaptive governance of social-ecological systems. Annual Review of Environment and Resources 30 (1), 441e473.

Gallopin, G.C., Funtowicz, S., O'Connor, M., Ravetz, J., 2001. Science for the twenty-first century: from social contract to the scientific core. International Social Science Journal 53 (168), $219 \mathrm{e} 229$.

Gamble, L.R., McGarigal, K., Jenkins, C.L., Timm, B.C., 2006. Limitations of regulated "buffer zones" for the conservation of marbled salamanders. Wetlands 26 (2), 298e306.

Gamble, L.R., McGarigal, K., Compton, B., 2007. Fidelity and dispersal in the pond-breeding amphibian, Ambystoma opacum: implications for spatio-temporal population dynamics and conservation. Biological Conservation 139 (3-4), 247e257.

Gibbons, J.W., Winne, C.T., Scott, D.E., Willson, J.D., Glaudas, X., Andrews, K.M., et al., 2006. Remarkable amphibian biomass and abundance in an isolated wetland: implications for wetland conservation. Conservation Biology 20 (5), 1457e1465.

Gibbs, J.P., 2000. Wetland loss and biodiversity conservation. Conservation Biology 14 (1), 314e317.

Gibbs, J.P., Reed, J.M., 2008. Population and genetic linkages of vernal-pool associated amphibians. In: Calhoun, A.J.K., deMaynadier, P.G. (Eds.), Science and Conservation of Vernal Pools in Northeastern North America. CRC Press, Boca Raton, Florida, pp. 149e167.

Greiner, R., Patterson, L., Miller, O., 2009. Motivations, risk perceptions and adoption of conservation practices by farmers. Agricultural Systems 99 (2), 86e104.

Grodzinska-Jurczak, M., Tomal, P., Tarabula-Fiertak, M., Nieszporek, K., Read, A.D., 2006. Effects of an educational campaign on public environmental attitudes and behaviour in Poland. Resources Conservation and Recycling 46 (2), $182 \mathrm{e} 197$.

Hair, J.F., Black, W.C., Babin, B.J., Anderson, R.E., Tatham, R.L., 2006. Multivariate Data Analysis, Sixth ed. Pearson Education Inc, Upper Saddle River, New Jersey.

Halseth, G., Booth, A., 2003. "What works well; what needs improvement": lessons in public consultation from British Columbia's resource planning processes. Environmental Studies 8 (4), 437e455.

Hart, D.D., Calhoun, A.J.K., 2010. Rethinking the role of ecological research in the sustainable management of freshwater ecosystems. Freshwater Biology 55, 258e269.

Hunter, L.M., Rinner, L., 2004. The association between environmental perspective and knowledge and concern with species diversity. Society and Natural Resources 17 (6), 517e532.

Illes, J., Moser, M.A., McCormick, J.B., Racine, E., Blakeslee, S., Caplan, A., et al., 2010. Neurotalk: improving the communication of neuroscience research. Neuroscience 11 (1), 61e69. 
Johnson, B.B., Pflugh, K.K., 2008. Local officials' and citizens' views on freshwater wetlands. Society and Natural Resources 21 (5), 387e403.

Kates, R.W., Clark, W.C., Corell, R., Hall, J.M., Jaeger, C.C., Lowe, I., et al., 2001. sustainability science. Science 292 (5517), 641e642.

Kempton, W., Boster, J.S., Hartley, J.A., 1996. Environmental Values in American Culture. The MIT Press, Cambridge, Massachusetts.

King, D.L., 1985. Nutrient cycling by wetlands and possible effects of water levels. In: Prince, H.H., D'Itri, F.M. (Eds.), Coastal Wetlands. Lewis Publishers, Chelsea, Michigan, pp. 69e86.

Larson, K.L., Lach, D., 2008. Participants and non-participants of place-based groups: an assessment of attitudes and implications for public participation in water resource management. Journal of Environmental Management 88 (4), 817e830.

Likert, R., 1932. A technique for the measurement of attitudes. Archives of Psychology 140 (55).

Lubchenco, J., 1998. Entering the century of the environment: a new social contract for science. Science 279 (5350), 491e497.

McCleery, R.A., 2009. Improving attitudinal frameworks to predict behaviors in human-wildlife conflicts. Society and Natural Resources 22 (4), 353e368.

Mitchell, J.C., Paton, P.W.C., Raithel, C.J., 2007. The importance of vernal pools to reptiles, birds, and mammals. In: Calhoun, A.J.K., deMaynadier, P.G. (Eds.), Science and Conservation of Vernal Pools in Northeastern North America. CRC Press, Boca Raton, Florida, pp. 169e190.

Nisbet, M.C., Scheufele, D.A., 2009. What's next for science communication? Promising directions and lingering distractions. American Journal of Botany 96 (10), 1767e1778.

Nisbet, M.C., 2009. Communicating climate change: why frames matter for public engagement. Environment: Science and Policy for Sustainable Development 51 (2), 12e23.

Nixon, H., Saphores, J.D.M., 2007. Financing electronic waste recycling Californian households' willingness to pay advanced recycling fees. Journal of Environmental Management 84 (4), 547 e559.

Norton, B.G., 1998. Improving ecological communication: the role of ecologists in environmental policy formation. Ecological Applications 8 (2), 350e364.

Patton, M.Q., 2002. Qualitative Research and Evaluation Methods, Third ed. Sage Publications, Inc., Thousand Oaks, California.

Preisser, E.L., Kefer, J.Y., Lawrence, J.D., Clark, T.W., 2000. Vernal pool conservation in Connecticut: an assessment and recommendations. Environmental Management 26 (5), 503e513.

Rispoli, D., Hambler, C., 1999. Attitudes to wetland restoration in Oxfordshire and Cambridgeshire, UK. International Journal of Science Education 21 (5), 467e484.

Sah, J.P., Heinen, J.T., 2001. Wetland resource use and conservation attitudes among indigenous and migrant peoples in Ghodaghodi Lake area. Nepal. Environmental Conservation 28 (4), 345 e356.

Schaaf, K.A., Ross-Davis, A.L., Broussard, S.R., 2006. Exploring the dimensionality and social bases of the public's timber harvesting attitudes. Landscape and Urban Planning 78 (1/2), 135e146.

St John, F.A.V., Edwards-Jones, G., Jones, J.P.G., 2010. Conservation and human behaviour: lessons from social psychology. Wildlife Research 37 (8), 658e667.

Stevens, J.P., 2002. Applied Multivariate Statistics for the Social Sciences, Fourth ed. Lawrence Erlbaum Associates, Inc., Mahwah, New Jersey.

Sullivan, K.A., Napier, T.L., 2005. Anticipated socio-environmental impacts of the proposed little Darby National wildlife Refuge in Ohio. Journal of Environmental Management 74 (1), 53 e64. 
Tarrant, M.A., Overdevest, C., 1997. The effect of persuasive communication strategies on rural resident attitudes toward ecosystem management. Society and Natural Resources 10 (6), 537 e550.

Thompson, S.C.G., Barton, M.A., 1994. Ecocentric and anthropocentric attitudes towards the environment. Journal of Environmental Psychology 14, $149 \mathrm{e} 157$.

Vaske, J.J., 2008. Survey Research and Analysis: Applications in Parks, Recreation and Human Dimensions. Venture Publishing, Inc., State College, Pennsylvania.

van Wyk, E., Roux, D.J., Drackner, M., McCool, S.F., 2008. The impact of scientific information on ecosystem management: making sense of the contextual gap between information providers and decision makers. Environmental Management 41 (5), 779e791.

van Kerkhoff, L., Lebel, L., 2006. Linking knowledge and action for sustainable development. Annual Review of Environment and Resources 31 (1), 445e477.

Weber, J.R., Word, C.S., 2001. The communication process as evaluative context: what do nonscientists hear when scientists speak? BioScience 51 (6), 487e495.

Windmiller, B., Calhoun, A.J.K., 2008. Population and genetic linkages of vernal-pool associated amphibians. In: Calhoun, A.J.K., deMaynadier, P.G. (Eds.), Science and Conservation of Vernal Pools in Northeastern North America. CRC Press, Boca Raton, Florida, pp. 233 e251. 